\title{
ENHANCING VOCABULARY KNOWLEDGE AMONG SECONDARY SCHOOL EFL STUDENTS BY USING FACEBOOK
}

\author{
Majida Ibrahim MUKHLIF \\ ORCID: 0000-0002-0955-8663 \\ Ministry of Education \\ General Directorate of Education in Al-Anbar \\ Anbar, IRAQ \\ Dr. Ala'a Ismael CHALLOB \\ ORCID: 0000-0002-4911-0644 \\ College of Education for Humanities \\ University Of Anbar \\ Anbar, IRAQ
}

Received: 04/08/2020 Accepted: 28/01/2021

\begin{abstract}
This study attempted to compare the effectiveness of employing Facebook and traditional instruction in improving Iraqi EFL secondary school students' vocabulary knowledge. The factors that positively and negatively affect the EFL students' vocabulary learning were also investigated. The study employed a quasiexperimental design with two groups; the control and the experimental groups. In the control group, thirty-six students were taught English vocabularies via the in-class conventional method, and the experimental group which consisted of another thirty-six students were taught using Facebook as an Online Learning Platform (FOLP) to enhance their knowledge of English vocabularies. A mix of quantitative and qualitative research methodology was used where triangulation of pretest, posttest, semi-structured interview and observation were used. Results showed that FOLP was more effective than traditional instruction in improving EFL students' vocabulary knowledge. In addition, results indicated that a variety of teaching techniques, effective group work, immediate feedback, and autonomous learning opportunities are factors that positively affect students' learning of English vocabularies. Moreover, students perceived that domination of the good students of the discussion, technical problems, and social loafing are the factors that negatively affect their learning of English vocabularies. The results confirmed the liability of using Facebook in broader contexts.
\end{abstract}

Keywords: English vocabulary knowledge, facebook, secondary school, EFL students.

\section{INTRODUCTION}

Globalization has created great changes in the education field. Today, information technology has simplified learning and gaining knowledge instead of using books and libraries. Individuals can gain access to various types of education with Computer-Mediated Communication (CMC) tools. Accordingly, teaching and learning have incorporated with (CMC) and become less physically binding and more beneficial (Talan \& Gulsecen, 2019; Aznar, et al., 2020).

Hence, to reduce the gap between what was used to be teacher-centred scenario and the formation of the Net Generation, educators need to incorporate self-directed learning strategies among students. In this way, they would be able to move away from the stereotypical teacher-oriented teaching and learning method and become autonomous learners (Blachowicz \& Fisher, 2006; Challob, 2018; Abdullah, et al., 2019).

In this digital era, CMC have played a vital role in teaching and learning the various skills and elements of English language. English vocabulary learning is one of the English language elements that were affected by the use of CMC in general, and Facebook in particular (Jafari \& Chalak, 2016; Lee, 2019; Motlagh, et al., 
2020). English vocabulary refers to the students' knowledge of various forms of words, their equivalences, and their appropriate use in everyday life meaningful situations (Cetinkaya \& Sutcu, 2018). This is because through Facebook, students can be provided with ample learning opportunities to gain new vocabularies and practice them continuously with their classmates in Facebook platform. As Steven Stahl (2005) cited in Blachowicz \& Fisher (2006), vocabulary knowledge can be deepened and enriched over time, and is not something that can ever be fully mastered. Therefore, integrating Facebook in learning vocabulary is an alternative way of teaching and learning in this globalized world.

Guidelines and demonstrations on classroom teaching and learning using Facebook are in abundance on the internet and in the past literature (Monica-Ariana \& Anamaria-Mirabela, 2014; Tosun, 2015; Jafari \& Chalak, 2016; Cetinkaya \& Sutcu, 2018; Lee, 2019; Motlagh, et al., 2020).They did not only explain the merits and demerits of using Facebook as a learning platform but they also provided scientific evidence for using Facebook for teaching and learning and deliver various supporting pedagogical ideas based on the use of Facebook. In addition, students have to understand English to be able to participate in the learning/ teaching activities of Facebook since most of its features are in English. The authentic language communication available on Facebook can be utilized to cultivate students' motivation and performance of the English language (Blattner \& Fiori, 2009).

As mentioned by Shahrokni (2009) and Cetinkaya \& Sutcu (2019), the use of multimedia tools or online applications in teaching and learning enhances students' vocabulary learning. This is further supported by Pennington (1989) who stated that when using a computer, incidental learning is effective. The acquisition of vocabulary allows students to speak and write fluently and helps them to understand the exact meaning of what they hear and read.

In the educational field, proficiency in English is an important requirement for students' success as it provides opportunities for them to build their future. Therefore, teachers need to improve students' English proficiency by enhancing their vocabulary knowledge. Vocabulary development is one of the key elements that open the door to educational success. Unfortunately, in an EFL setting in Iraq, students' lack of direct and indirect exposure to English language vocabularies resulted from the constant use of their mother tongue inside and outside the classroom and the insufficient language exposure outside the classroom. This created weak students in the English language.

However, secondary school EFL students lack in their grasp in vocabulary and this is considered one of the factors that hinder their communication with others. Their exposure to English is limited to the classroom environment during English lessons only. Shedding light on this serious problem, the researchers tapped students' interest in using Facebook to inculcate their vocabulary knowledge by providing them with Facebooksupported learning activities that enrich their vocabulary knowledge. Hence, it is hoped that EFL students can be able to communicate better, construct meaningful sentences, and improve their English performance.

In this study, the researchers attempted to compare the effectiveness of employing FOLP and traditional instruction in improving vocabulary knowledge among Iraqi EFL secondary school students. The factors that positively and negatively affect the EFL students' vocabulary learning were also targeted. Accordingly, the following research questions were addressed:

1 - Is there any difference in the EFL students' vocabulary knowledge between the students who used FOLP and those who received traditional instruction?

2- Is there any difference in the EFL students' English vocabulary knowledge before and after the experiment for the experimental group and the control group?

3- How do the EFL students perceive the determining factors that enhance and hinder their learning of English vocabulary in FOLP?

\section{SIGNIFICANCE OF THE STUDY}

Generally, the study is intended to investigate and explore the effectiveness of using Facebook as a platform of learning as compared with the traditional teaching method in enhancing students' vocabulary knowledge. The results of this study would provide an insight to secondary school EFL students, teachers, and textbooks designers and the practitioners in the field of English language learning and teaching. 
As for the EFL students, the results of the study can help them get direct exposure to many vocabularies of various classes and be familiar with their meanings and usages. Adding to that, the use of Facebook as a platform of learning English vocabularies is new and attractive to EFL students. Thus, it can encourage them, motivate them, and immerse them in a creative learning environment. It can also help EFL students' continue their learning outside the time and place of the traditional classroom.

As for English language teachers, the use of Facebook can help them be in direct contact with his/her students without any restrictions. It can also help the English language teachers create language learning activities and discussion activities among the students and help them learn by themselves autonomously.

With reference to the significance of this study to textbooks designers and practitioners, the results of the study can provide them with useful theoretical and practical pedagogical evidences and recommendations for the effectiveness of utilizing Facebook in improving the EFL students' vocabulary knowledge. Consequently, these pedagogical evidences and recommendations can help improve students' English proficiency level, in general and enrich EFL students' vocabulary knowledge, in particular.

\section{LITERATURE REVIEW}

Vocabulary learning is a collective process whereby learners gather and store vocabularies learned in the lexical memory of the brain (Rose, 2006). Learners need constant opportunities to use the gathered words appropriately and thus gain an understanding of their use. There is a strong connection between vocabulary knowledge of readers and their ability to understand what they read (Blachowitz \& Fisher, 2006). According to Schmitt \& McCarthy (1997), good vocabulary instruction focuses on important words that help students understand the text, use words that students deal with frequently, and difficult words like idiomatic words; words with more than one meaning. Teachers, therefore, can help students by encouraging them to learn new words and enhancing their word knowledge through proper vocabulary instruction. According to Liu (2009), teachers should teach their students how to learn new words instead of just teaching them vocabulary. S/he stresses that activities used in the classroom should be learners-centered so that students could be independent learners and they could deal better with unknown words in context.

Various researches (Abdullah, et al., 2019; Challob, 2018; Dehham, 2018; Waring, 2008) have shown that effective participation in language and vocabulary learning makes learners learn better. They concluded that learners must form groups and practice the use of new words to avoid keeping words isolated and allow them to notice new words for themselves and assume the meaning of the new words.

Several studies like (Challob, et al., 2016; Shetzer \& Warschauer, 2000) have stated that the Internet has now become one of the primary media for literacy and communication practices, opening multiple channels of communication for interpersonal contact, group discussion, and information exchange.

In addition, numerous studies have revealed the advantages of using CMC as the medium to support the learning process. Some of the advantages are as follows. Firstly, it produces a good equitable platform and decreases threatening forums for second language acquisition (SLA) discussion (Warschauer, 1996). Secondly, it shows an increase in sharing ideas and knowledge among students. Thirdly, it results in a more decentralized role of teacher and develops the quantity of the output of language (Kern, 1996). Finally, it enhances learners' attention to linguistic form as a text-based medium (Warschauer, 1996).

Facebook can be defined as online groups that can share photographs, personal, and educational information within an online social network site (Buckman, 2005 \& Majida, 2020). Similar to CMC, several studies (Cheung \& Vogel, 2011; Khe, 2011; Shahrokni, 2009) have revealed that there are positive inputs in using Facebook as a medium to support learning. Some of the skills can be useful for language learners by including them in online discussion platforms and searching for new information to improve their skills in a more informal way and give students the chance to learn so many practical skills. For example, Northcote and Kendle (2001) stated that learning via Facebook enhances students' critical analysis skills, resources, and it is also an active online interaction platform for filtering and decoding information. In addition, Roth (2009) indicated that teaching and learning should be interactive, personalized and holistic that aid students to move away from the passive realm of reading into the interactive world of digital pedagogy, as well technology should be made significant component in the curriculum by drawing Plato's goals for 
education and adapting and realizing them. Therefore, the use of language in Facebook in terms of dialogues in conversational contexts can help learners in enhancing their vocabulary skills and knowledge.

As for the use of Social Networking Sites (SNSs) in general, and Facebook in particular in teaching English vocabulary, several studies have been conducted in various English language contexts. For example, Nikbakht and Boshrabadi (2015) explored the benefits of using Facebook as a Social Networking Site in developing Iranian EFL students' vocabulary knowledge. In addition, Motlagh, et al. (2020) investigated the effect of some educational videos, text material delivered through the use of social networks (i.e. Telegram) on EFL undergraduate students' vocabulary knowledge in Iran. The results of these two studies were positive in terms of improvement in students' vocabulary knowledge. Furthermore, Lee (2019) investigated the extent of the effect of quantity (frequency/amount of time) and quality (diversity) students' exposition to informal digital learning of English vocabularies on (L2) students' quality in vocabulary outcomes. The study concluded that the quantity of informal digital learning of English vocabularies was not associated with students' vocabulary outcomes and the quality of informal digital learning of English vocabularies was positively related to students' vocabulary outcomes. Moreover, Tosun (2015) investigated the effects of using blended learning strategy in enhancing EFL students' vocabulary and concluded that the use of blended learning strategy was effective in enriching EFL students' vocabulary. Besides, Jafari and Chalak (2016) investigated the effect of WhatsApp in improving Iranian junior high school EFL students' vocabulary learning. The findings revealed significantly positive effect of using WhatsApp on students' learning of English vocabularies. Cetinkaya and Sutcu (2018) conducted a study to compare between the effect of using WhatsApp and Facebook on English vocabulary instruction. The findings revealed that WhatsApp is more effective than Facebook in teaching English vocabulary.

Other studies (Monica-Ariana and Anamaria-Mirabela, 2014; Kabilan and Zahar, 2016) investigated the effectiveness of using social media, namely; Facebook to enrich students' vocabulary knowledge. To some extent, these two studies resulted in conflicting findings. The findings of Monica-Ariana and AnamariaMirabela (2014) study indicated that there was no significant difference between the control and experimental groups though the use of Facebook helped in improving the vocabulary knowledge in the two groups. As for Kabilan and Zahar (2016) study, it was found that the students performed better in the post-test as compared to the pre-test due to the use of Facebook in learning English vocabulary. Based on the findings of the aforementioned previous studies, there are contradictory evidences for the effectiveness of Facebook in improving students' vocabulary knowledge. In addition, the factors that help student' enrich their vocabulary knowledge or hider it were not investigated in the past studies. Accordingly, the current study aimed at investigating the effect of Facebook in enhancing EFL students' vocabulary knowledge. Besides, the determining factors that enhance and hinder EFL students' learning of English vocabulary were also addressed in the current study.

\section{METHODOLOGY}

This section presents details relevant to the research design, methods of collecting data, and analyzing.

\section{Research Design}

The mixed-method research design methodology was implemented in the current study, whereby it combines the quantitative and qualitative approaches of data collection in a single study (Creswell, (2014). According to Gay, et al. (2009), the use of quantitative and qualitative methods together develops the interconnection and strength that exists between them to understand the phenomena completely. The type of mixed-method research design that was used for this study was the QUANTI-QUALI Model which is also known as the explanatory mixed methods design (Denzin \& Lincoln, 2018).

In addition, the quantitative research method that was used in this study was the Quasi-experimental design since it was not possible for the researcher to randomly allocate subjects. This method helped the researchers to sufficiently control the threats of validity. The non-equivalent control group design was chosen as it was like the pretest-posttest control group design except it did not involve random allocation. If differences between the groups on any major extraneous variables were detected, analysis of covariance (ANCOVA) could be used to statically equate the groups (Newby, 2014). As for the qualitative data, they were collected by using a semi-structured interview and observation. 


\section{Participants}

Seventy-two students were chosen from one of the secondary schools in Erbil in the north of Iraq in the academic year 2019-2020. Those students were enrolled in an English as a foreign language course as a prescribed course in their 4th secondary year. They were all having the same proficiency level in English language as they upgraded from the $3^{\text {rd }}$ academic year to the $4^{\text {th }}$ academic year under the same educational system and conditions. The participants' ages ranged from sixteen to seventeen years old. They were homogenous in their gender, cultural background, mother tongue (Arabic), and the number of years of studying EFL. Though they were proficient in using Facebook to socially communicate with each other and for posting in a daily base, they have ever utilized it as a learning platform of English language. Before this semester, they were learning English language using the traditional Face-to-Face in class method.

Thirty-six students formed the experimental group and another thirty-six students acted as the control group subjects. Ten students from the experimental group were purposively selected to participate in the interview. The selection of the interviewees was based on their exposure to the teaching instruction, their performance, and engagement in the course ( 3 students are good, 4 students are medium, and 3 students are low) in their performance and engagement in the course.

\section{Instruments}

A triangulation of mixed-mode research instruments was used for data collection as described below:

1- Quantitative research instruments: They include the pretest represented by mini dialogues with omitting unneeded letters and the posttest represented by a crossword puzzle. The items in the pretest and posttest were developed based on the English language syllabus of the prescribed book entitled (English for Iraq) for the 4th year secondary school students. Then, the researchers ensured the face and content validity of the pretest and posttest by submitting them to a jury of five experts. Some amendments to the pretest and posttest were performed based on the experts' suggestions. Finally, the pretest and posttest were piloted to ensure their content and language clarity, accuracy, practicality, and reliability. Based on the Cronbach's Alpha values which should be more than 0.7 (Hair et al, 2017), the reliability value for the pre-test was (0.91) and the post-test was (0.89). These values represented that the two tests were highly reliable.

2- Qualitative research instruments: They include semi-structured interview and observation notes. The interview questions were submitted to the same jury of experts who also suggested some constructive recommendations to the questions of the interview to be amended by the researchers. It is worth noting that the interview was conducted by using the students' mother tongue; Arabic language, depending on the preference of the interviewees. Fortunately, this procedure helped the researchers to collect detailed answers and rich of information discussion from the interviewees. The students' answers were transcribed verbatim and translated by the researchers into the English language. The English version of the students' interview answers was submitted to an expert in the field of linguistics and translation for the purpose of validation and back translation.

\section{Data Collection Procedures}

The study was carried out in three phases as explained below:

1- Pre-Study Phase (Week-1): The students in the experimental and control groups were given a pretest.

2- The treatment phase (Week -2 to Week -11): The teacher taught the students in the experimental group using FOLP. Thus, the teacher provided the students with English vocabulary exercises and activities to be performed online via Facebook at an allocated time (online communication outside the classroom). The students were informed to attend four online hours on Facebook each week. As for the control group, students were taught by using the traditional method in their normal classroom. It is worth noting that the teacher- who was one of the researchers- of the experimental group and the control group was the same. 
3- Post-Study Phase (Week -12): The students in the experimental and control groups were asked to do the posttest. In addition, a semi-structured interview was conducted to the experimental group to determine the students' perceptions relevant to the factors that affected their learning of English vocabulary. Figure 1 illustrates the procedures of data collection of this study.

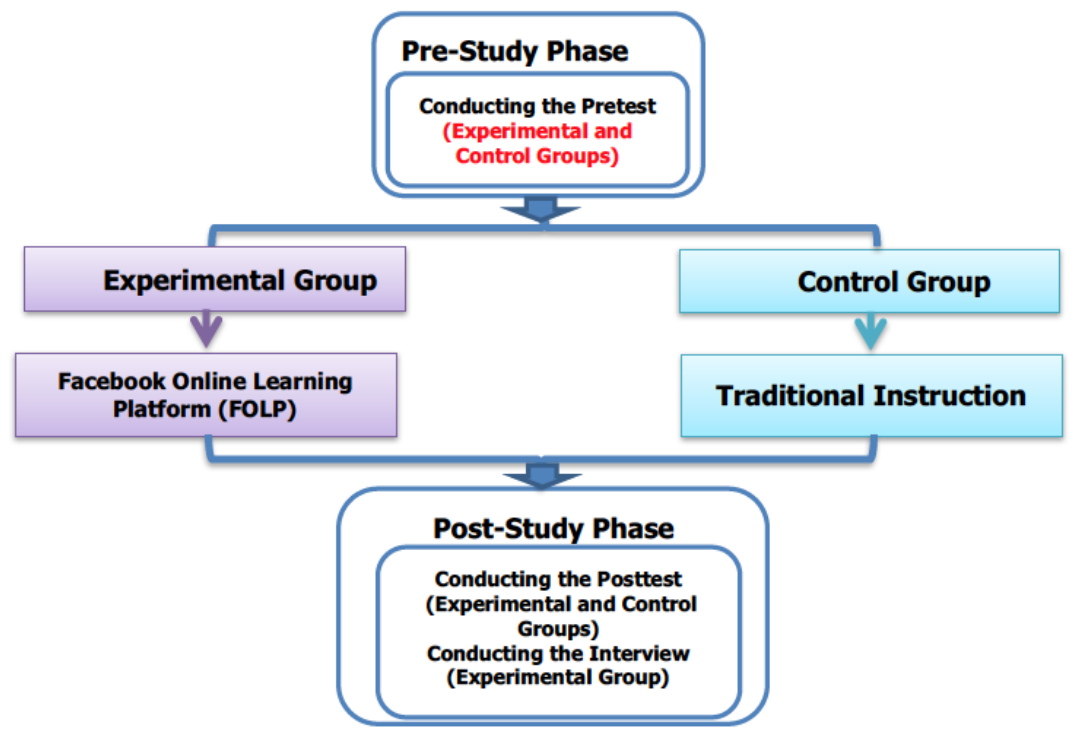

Figure 1. Procedures of the study.

\section{Data Analysis Procedures}

As for the quantitatively collected data; they were analyzed using the Statistical Package for the Social Sciences (SPSS Version 21) software. SPSS was used to get the descriptive statistics to show the number of subjects and to compare the means, standard deviation, and standard error of the experimental and control group in the pretest and posttest. In this study, ANCOVA was used to compare the differences in English Language vocabulary knowledge between the students who used FOLP and those who used traditional instruction. ANCOVA was utilized as the researchers were unable to randomly assign subjects to different groups but instead having to use the existing groups (e.g., classes of students). To identify the differences in the mean scores of the students' pretest and posttest for the Facebook group and the traditional instruction group respectively, the paired samples T-test was used.

As for the data collected qualitatively by using the semi-structured interview, and observation, they were analyzed qualitatively following the six phases of thematic analysis suggested by Creswell (2012). These steps are; preparing and organizing the data, exploring and coding the data, describing findings and forming themes, representing and reporting findings, interpreting the meaning of the findings, and ensuring credibility and trustworthiness of the findings.

To prepare and organize the data, the researchers transcribed the data collected by the students' interviews following verbatim transcription technique, typed the Arabic version of the interview responses, and saved them using Microsoft files. Then, the researchers translated the Arabic version of the students' interviews into English language and gave it to one expert in English- Arabic translation from the department of English, College of Education for Humanities-University of Anbar. He was asked to check the accuracy and compatibility of the meaning in both the Arabic and English versions. As for the observation notes, they were also types and saved as Microsoft files. Finally, the data were arranged and organized in tables. For the purpose of exploring and coding the data, the data were insightfully read for many times, and categorized. In addition, the researchers wrote some descriptive notes for these categories to develop deep understanding of the data and to arrive at the emerging themes relevant to the research questions of the current study. In describing findings and forming themes, the data were re-read again carefully to create broad themes that combine the sub-themes and categories emerged. Accordingly, these themes were categorized into main 
themes and sub-themes according to the research questions of the current study. This phase is followed by scientifically reporting the findings and providing them with the required explanations and interpretations.

Finally, to certify the reliability, objectivity, and credibility of the findings emerged from the qualitative data and avoid the researchers' bias, triangulation and review by external auditors were implemented by the researchers (Stake, 2010; Yin, 2011). First, multiple data collection instruments were implemented for the purpose of triangulation of data and to compare them to ensure their accuracy and compatibility. This is ensured by checking out the stability of the findings obtained by various data collection sources (Denzin \& Lincoln, 2018). Second, the researchers submitted the first draft of the analysis and the findings to an external auditor to scientifically and critically study the entire research process and provide constructive comments in terms of the strengths and weaknesses of the findings. This expert was a professional and long experience professor in the field of technology and English language teaching. He critically examined the accuracy of all stages of the research process and confirmed the validity and accuracy of the findings. Finally, to ensure the objectivity of the analysis and the accurateness of the themes emerged from the students' interviews and observation notes, inter-rater reliability was calculated (Creswell, 2014). To do this, the collected data were coded by two coders: the first one was one of the researchers, whereas the second one was the external auditor mentioned above. An agreement percentage between the two coders was calculated relevant to the coded patterns. The result was (96\%) for the two coders' agreement. Then, the disagreement point related to some themes were discussed again by the two coders and resulted in a (98\%) percent of agreement between them.

\section{RESULTS OF THE STUDY}

The following sections cover a detailed survey of the results of the study described in terms of the previously stated research questions.

\section{Quantitative Results}

\section{Results of the First Research Question}

Table 1, 2, and 3 provide the ANCOVA results for the differences in English Language vocabulary knowledge between students who were taught by using FOLP and those who were taught by using the traditional instruction as calculated by the students' scores in the posttest.

Table 1. Descriptive Statistics of the Difference between the Control and the Experimental Groups as Measured by their Posttest Scores.

\begin{tabular}{llll}
\hline \multicolumn{4}{c}{ Dependent Variable: Posttest } \\
\hline Groups & Mean & Std. Deviation & Number \\
\hline Control Group & 19.6389 & 8.50597 & 36 \\
Experimental Group & 22.0278 & 8.25828 & 36 \\
Total & 20.8333 & 8.41026 & 72 \\
\hline
\end{tabular}

As shown in Table 1 above, the results gained from the students' posttest on both groups show that the mean score of the experimental (22.0278) is higher than that of the control group (19.6389). This means that the students' vocabulary knowledge of the experimental group is better than that of the control group.

Table 2 shows that the assumption of equality variance is not violated. The significant level is 0.112 , which is greater than 0.05 . Thus, the variances are equal and the assumption is not violated. 
Table 2. Levene's Test of Equality of Error Variances.

\begin{tabular}{llll}
\hline \multicolumn{3}{c}{ Dependent Variable: Posttest } \\
\hline $\mathrm{F}$ & $\mathrm{df} 1$ & $\mathrm{df} 2$ & Level of Significance \\
2.591 & 1 & 70 & .112 \\
\hline
\end{tabular}

* Tests the null hypothesis that the error variance of the dependent variable is equal across groups.

a. Design: Intercept + pretest + method.

The statistical details mentioned in Table 3 clearly portray the statistically significant difference between the group of students who were taught by using FOLP and those who were taught by using traditional instruction in terms of the EFL students' vocabulary knowledge.

Table 3. Tests of Between-Subjects Effects.

\begin{tabular}{|c|c|c|c|c|c|c|c|c|}
\hline \multicolumn{9}{|c|}{ Dependent Variable: Posttest } \\
\hline Source & $\begin{array}{l}\text { Type III Sum } \\
\text { of Squares }\end{array}$ & df & $\begin{array}{l}\text { Mean } \\
\text { Square }\end{array}$ & $\mathrm{F}$ & $\begin{array}{c}\text { Level of } \\
\text { Significance }\end{array}$ & $\begin{array}{c}\text { Partial } \\
\text { Eta } \\
\text { Squared }\end{array}$ & $\begin{array}{l}\text { Noncent. } \\
\text { Parameters }\end{array}$ & $\begin{array}{c}\text { Observed } \\
\text { Power a }\end{array}$ \\
\hline $\begin{array}{c}\text { Corrected } \\
\text { Model }\end{array}$ & $3278.168 b$ & 2 & 1639.084 & 64.855 & .000 & .653 & 129.711 & 1.000 \\
\hline Intercept & 298.033 & 1 & 298.033 & 11.793 & .001 & .146 & 11.793 & .923 \\
\hline Pretest & 3175.446 & 1 & 3175.446 & 125.646 & .000 & .646 & 125.646 & 1.000 \\
\hline Group & 102.722 & 1 & 102.722 & 4.065 & .048 & .056 & 4.065 & .511 \\
\hline Error & 1743.832 & 69 & 25.273 & & & & & \\
\hline Total & 36272.000 & 72 & & & & & & \\
\hline $\begin{array}{c}\text { Corrected } \\
\text { Total }\end{array}$ & 5022.000 & 71 & & & & & & \\
\hline \multicolumn{9}{|c|}{ a. Computed using Alpha $=0.05$} \\
\hline \multicolumn{9}{|c|}{ b. R Squared = 0.653 (Adjusted R Squared $=0.643$ ) } \\
\hline
\end{tabular}

As shown in Table 3, the significant level is higher than 0.05 . Therefore, there is a statistically significant difference in the mean scores of the posttest between the group of students who used FOLP and those who received the traditional instruction on the English language vocabulary knowledge after controlling the effect of the mean score of the pretest $(\mathrm{F}=4.065 ; \mathrm{df}=1 ; \mathrm{p}=0.48)$. This significant difference is in favour of the first group; i.e., the group taught by using FOLP. Thus, it can be concluded that FSBLP is more effective than traditional instruction in improving English language vocabulary knowledge.

\section{Results of the Second Research Question}

Table 4, and 5 show the results of the Paired-samples T-test for the difference in the students' English vocabulary knowledge of the experimental group members who were taught by using FOLP before and after instruction as measured by the students' pretest and posttest mean scores.

Table 4. Paired Samples Statistics of the Difference between the Mean Scores of the Pretest and Posttest of the Experimental Group.

\begin{tabular}{lllll}
\hline & Mean & Number & Std. Deviation & Std. Error Mean \\
\hline Pair Pretest & 20.1667 & 36 & 8.68990 & 1.44832 \\
1 Posttest & 22.0278 & 36 & 8.25828 & 1.37638 \\
\hline
\end{tabular}


As shown in Table 4 above, the mean score of the posttest (22.0278) is higher than that of the pretest (20.1667). This means that the use of FOLP has improved the students' English vocabulary knowledge. Table 5 indicates whether there is a statistically significant difference between the mean scores of the English vocabulary test before and after the experiment.

Table 5. Paired Samples T-Test of the Difference between the Mean Scores of the Pretest and Posttest of the Experimental Group.

\begin{tabular}{|c|c|c|c|c|c|c|c|c|}
\hline & \multicolumn{5}{|c|}{ Paired Differences } & \multirow{3}{*}{$\mathrm{t}$} & \multirow{3}{*}{$d f$} & \multirow{3}{*}{$\begin{array}{c}\text { Sig. } \\
\text { (2-tailed) }\end{array}$} \\
\hline & & & \multirow{2}{*}{$\begin{array}{l}\text { Std. } \\
\text { Error } \\
\text { Mean }\end{array}$} & \multicolumn{2}{|c|}{$\begin{array}{l}\text { 95\% Confidence Interval } \\
\text { of the Difference }\end{array}$} & & & \\
\hline & Mean & $\begin{array}{c}\text { Std. } \\
\text { Deviation }\end{array}$ & & Lower & Upper & & & \\
\hline $\begin{array}{l}\text { Pair } 1 \text { Pretest- } \\
\text { Posttest }\end{array}$ & -1.86111 & 4.63621 & .77270 & - .3.42978 & -.29244 & 2.409 & 35 & .021 \\
\hline
\end{tabular}

Based on the result shown in Table 5, the significance level is lower than $0.05(t=2.409 ; d f=35 ; p=0.021)$, which led to the conclusion that there is a statistically significant difference in the English language vocabulary knowledge before and after the experiment for the students in the experimental group. This significant difference is in favour of the posttest; i.e., the students in the experimental group who were taught by using FOLP were better in their posttest as compared with their performance in the pretest.

\section{Results of the Third Research Question}

Table 6 and 7 show the results of the Paired-samples T-test for the difference in the English language vocabulary knowledge of the control group who were taught by using the traditional instruction as measured by the students' pretest and posttest mean scores.

Table 6. Paired Samples Statistics of the Difference between the Mean Scores of the Pretest and Posttest of the control Group.

\begin{tabular}{ccccc}
\hline & Mean & Number & Std. Deviation & Std. Error Mean \\
\hline Pair Pretest & 20.1667 & 36 & 8.68990 & 1.44832 \\
1 Posttest & 19.6389 & 36 & 8.50597 & 1.41766 \\
\hline
\end{tabular}

Table 6 indicates that the mean score of the posttest (19.6389) is slightly lower than that of the pretest (20.1667). This means that the use of traditional instruction did not make any type of improvement in students' English vocabulary knowledge. Table 7 indicates whether there is a statistically significant difference between the mean scores of the English vocabulary test before and after the experiment for the control group.

Table 7. Paired Samples Test of the Difference between the Mean Scores of the Pretest and Posttest of the control Group.

\begin{tabular}{|c|c|c|c|c|c|c|c|c|}
\hline & \multicolumn{5}{|c|}{ Paired Differences } & \multirow{3}{*}{$\mathrm{t}$} & \multirow{3}{*}{ df } & \multirow{3}{*}{$\begin{array}{c}\text { Sig. } \\
\text { (2-tailed) }\end{array}$} \\
\hline & & & \multirow{2}{*}{$\begin{array}{l}\text { Std. Error } \\
\text { Mean }\end{array}$} & \multicolumn{2}{|c|}{$\begin{array}{l}\text { 95\% Confidence } \\
\text { Interval of the } \\
\text { Difference }\end{array}$} & & & \\
\hline & Mean & $\begin{array}{c}\text { Std. } \\
\text { Deviation }\end{array}$ & & Lower & Upper & & & \\
\hline Pair 1 Pretest- Posttest & .52778 & 5.99755 & .99959 & -1.50150 & 2.55706 & .528 & .35 & .601 \\
\hline
\end{tabular}


Based on the result in Table 7, the significance level is higher than $0.05(t=0.528 ; \mathrm{df}=35 ; \mathrm{p}=0.601)$. This leads to the conclusion that there is no statistically significant difference in the English language vocabulary knowledge for students of the control group before and after instruction.

\section{Qualitative Results}

\section{EFL Students' Improvement in their Vocabulary Knowledge}

Based on the quantitative results mentioned in the previous sections, it is found that the use of FOLP in teaching English vocabularies was statistically more effective as compared with traditional instruction. This result is also qualitatively confirmed when analyzing the students' responses to the semi-structured interview and observation. The majority of the interviewees ( 8 students out of ten students) indicated that they noticed a gradual enrichment on their vocabulary knowledge throughout FOLP. The following are extracts from the students' responses to the interview questions.

S1: I feel happy in learning the English language on Facebook. I feel that I have the required vocabulary wherever I need them in expressing myself.

S3: I think that the amount of vocabularies is better than before. I learned so many vocabularies during the course.

S4: We learnt so many vocabularies,......mmmmm, when we discuss with the teacher and with classmates, we shared so many vocabularies. hmmm....I feel now is better.

As for the other two students (S7, and S9), they also appreciated the use of Facebook as a platform of learning and viewed it as more flexible in terms of its time and place as stated by (S7), and it enhanced not only students' vocabulary knowledge, but it also encouraged them to speak as they have the number of vocabularies they need and it was psychologically not threatening as the case of the traditional instruction. Below are extracts from their responses to the interview questions.

S7: I feel more comfortable in Facebook learning since the teacher and classmates are always available for help as long as we are connected to the internet.

S9: Unlike the traditional instruction, in Facebook, we feel that there are no threatening factors when we discuss....mmm.... classmates also did not make fun from other students.

In addition, throughout the experiment, the students in the experimental group were noticed more active in their discussion as compared with those in the control group. They were also observed to utilize new vocabularies with their derivations. Some of them have prepared lists of vocabularies and their synonyms, and antonyms and share with their classmates on Facebook. Adding to that, students were able to use appropriate vocabularies to their context.

\section{Factors that Affect the EFL Students' Vocabulary Learning Positively}

In this section, the qualitatively collected data by using the students' interview, and observation notes were analyzed thematically. As a result of this thematic analysis, four themes emerged representing the factors that positively affect the EFL students' vocabulary learning as perceived by the members of the experimental group who were taught by the use of FOLP. These factors are presented and illustrated in Table 8. 
Table 8. Factors that Affect the EFL Students' Vocabulary Learning.

\begin{tabular}{|c|c|c|c|c|}
\hline No. & Factors & $\begin{array}{l}\text { Frequency of } \\
\text { students } \\
\text { (out of } 10 \text { students) }\end{array}$ & \multicolumn{2}{|c|}{ Examples from the students' interview extracts } \\
\hline \multirow[t]{3}{*}{1} & \multirow{3}{*}{$\begin{array}{l}\text { Variety of } \\
\text { the teaching } \\
\text { techniques and } \\
\text { activities }\end{array}$} & 7 & S3: & $\begin{array}{l}\text { Every lecture, we participate in different learning activities, } \\
\text { various vocabulary exercises. This is good for me as it keeps us } \\
\text { away from the class routine. }\end{array}$ \\
\hline & & & S5: & $\begin{array}{l}\text { The variety of modes of learning encourages us to learn better } \\
\text { in Facebook. }\end{array}$ \\
\hline & & & S10: & $\begin{array}{l}\text { Facebook is more motivating to me. } \mathrm{Hmmmm}, . . . \text { not only learn } \\
\text { from the material, sometimes I learn new vocabularies from } \\
\text { photos and animations available in our Facebook class. }\end{array}$ \\
\hline \multirow[t]{3}{*}{2} & \multirow[t]{3}{*}{$\begin{array}{l}\text { Effective group } \\
\text { work }\end{array}$} & 9 & S1: & $\begin{array}{l}\text { Group work activities help me not only in learning vocabularies, } \\
\text { but it develops my speaking ability. }\end{array}$ \\
\hline & & & S2: & $\begin{array}{l}\text { Facebook helps us to work in groups. This made me more } \\
\text { relaxed. I have friends that helped me and I help them to do the } \\
\text { activity and learn together. }\end{array}$ \\
\hline & & & S3: & $\begin{array}{l}\text { Facebook groups encourage me to learn outside the classroom } \\
\text { and be more creative because we have enough time to think } \\
\text { carefully. }\end{array}$ \\
\hline \multirow[t]{3}{*}{3} & \multirow[t]{3}{*}{$\begin{array}{l}\text { Immediate } \\
\text { feedback }\end{array}$} & 9 & S1: & $\begin{array}{l}\text { Facebook gives us a chance to get the direct correction. I feel } \\
\text { happy when working with my friends because they can help me, } \\
\text { and I also can help them. }\end{array}$ \\
\hline & & & S4: & $\begin{array}{l}\text { On Facebook, I feel comfortable because I can ask the } \\
\text { teacher whenever I encounter a language problem and get a } \\
\text { recommendation for my mistakes. }\end{array}$ \\
\hline & & & S7: & $\begin{array}{l}\text { When practicing language together on Facebook, it is so easy to } \\
\text { correct each other's mistakes. }\end{array}$ \\
\hline \multirow[t]{3}{*}{4} & \multirow{3}{*}{$\begin{array}{l}\text { Autonomous } \\
\text { learning } \\
\text { opportunities. }\end{array}$} & 6 & S8: & $\begin{array}{l}\text { The types of activities practiced on Facebook encourage us to } \\
\text { be more independent in our learning. }\end{array}$ \\
\hline & & & S9: & $\begin{array}{l}\text { Facebook platform gives us opportunities to learn by ourselves. } \\
\text { Sometimes I do exercises with friends even if the teacher is not } \\
\text { online. }\end{array}$ \\
\hline & & & S10: & $\begin{array}{l}\text { When working online, I can learn by myself. I can easily look } \\
\text { for language knowledge and new vocabularies from online } \\
\text { dictionaries, google..... }\end{array}$ \\
\hline
\end{tabular}

The aforementioned results emerged from the students' responses to the interview questions were also supported by the teacher's observation notes. Students were observed working actively and enthusiastically in FOLP, specifically when working in group form. They used to discuss with each other utilizing new vocabularies, share language and vocabulary knowledge, provide feedback, and correct each other's mistakes independently. Students were also noticed relaxed and enjoyed engaging and participating in the various language activities and materials posted on Facebook.

\section{Factors that Hinder the EFL Students' Vocabulary Learning}

Thematic analysis of the students' responses to the interview questions and observation revealed three themes relevant to the factors that negatively affect the EFL students' vocabulary learning as perceived by the members of the experimental group. These factors are described and illustrated in Table 9. 
Table 9. Factors that Hinder EFL Students' Vocabulary Learning.

\begin{tabular}{|c|c|c|c|c|}
\hline No. & Factors & $\begin{array}{l}\text { Frequency of } \\
\text { students } \\
\text { (out of } 10 \text { students) }\end{array}$ & \multicolumn{2}{|r|}{ Examples from the students' interview extracts } \\
\hline \multirow[t]{3}{*}{1} & $\begin{array}{l}\text { Domination of the } \\
\text { good students of the } \\
\text { discussion and work. }\end{array}$ & 7 & S3: & $\begin{array}{l}\text {....mmmm, sometimes the good student takes the } \\
\text { responsibility of the majority of the activity. Little work is } \\
\text { given to the other students. }\end{array}$ \\
\hline & & & S6: & $\begin{array}{l}\text { Ahh, I think, hmm, weak students depend on the students } \\
\text { who are better than them when doing a specific activity. }\end{array}$ \\
\hline & & & S9: & $\begin{array}{l}\text { "', students who have good speaking ability dominate on } \\
\text { the discussion. They did not give the other students time to } \\
\text { discuss. In this case, they impede our learning. }\end{array}$ \\
\hline \multirow[t]{3}{*}{2} & Technical problems & 4 & S4: & $\begin{array}{l}\text {....when we work in the activity, electricity power cut hinder } \\
\text { learning because I'll be offline and cannot continue with } \\
\text { friends in doing the activity for a few minutes }\end{array}$ \\
\hline & & & S5: & Weak signal caused a problem for me frequently. \\
\hline & & & S6: & $\begin{array}{l}\text { hmmm, Internet is not good in my house, sometimes is } \\
\text { cut and other time its signal is so weak. This interrupts our } \\
\text { discussion in the activity. }\end{array}$ \\
\hline \multirow[t]{3}{*}{3} & Social Loafing & 3 & S1: & $\begin{array}{l}\text { Sometimes, some students waste time in speaking outside } \\
\text { the activity. }\end{array}$ \\
\hline & & & S7: & $\begin{array}{l}\text { Students, } \mathrm{mmmm} \text {, sometimes, argue in other topics not } \\
\text { related to the activity we are doing. }\end{array}$ \\
\hline & & & S10: & $\begin{array}{l}\text { Some students, sometimes, leave the activity we are doing } \\
\text { and talk on another topic, hmmm, they did not work seriously } \\
\text { in the activity. This confused our learning. }\end{array}$ \\
\hline
\end{tabular}

As shown in Table 9, students' reflections in the interview clearly clarified the three factors that hinder English vocabulary learning. In addition, the analysis of the observation notes confirmed the same factors mentioned above. Sometimes, good students, specifically those that have good language commands used to take the whole discussion and responsibility for doing the activity. Accordingly, the teacher intervenes in this discussion and encourages the other students to participate and contribute to the activity. On some occasions, some students were seen not enrolled in the discussion for a short time or completely absent in the time of the activity. They claimed that there are technical problems represented by either temporary weak Internet signal or electricity cut and their Internet routers are not connected to UPS to help them be always online. Sometimes, few students were seen doing discussing outside the learning activity. These problems are normal in Iraq due to the various economic and political reasons.

\section{DISCUSSION}

Although the use of Facebook has been widely implemented socially and educationally, its effectiveness in improving EFL students' vocabulary knowledge as online learning English language environment is still neglected. Moreover, exploration of the factors that are available in this learning environment and that have positive and negative effects on EFL students' vocabulary knowledge is still ignored in past studies. The majority of past studies were concerned with using Facebook to enhance students' English language and communication among students themselves (Buckman, 2005; Blattner \& Fiori, 2009; Roth, 2009; Cheung \& Vogel, 2011; Khe, 2011). Other past studies such as (Liu, 2009; Sharokani, 2009; Ajisoko, 2020) were mainly concerned with using technology in general in teaching and learning English vocabularies. Some other studies (Rose, 2006; Dehham, 2018) investigated the use of other teaching techniques in teaching English vocabulary. Accordingly, the current study might be the first experimental study that integrated Facebook with conventional classes to examine its effectiveness in improving the EFL students' vocabulary knowledge and identify the determining factors that positively or negatively affected the EFL students' vocabulary knowledge. 
Results of the current study showed that the use of FOLP was significantly effective in improving the EFL students' vocabulary knowledge in favour of students of the experimental group as compared with students of the control group as measured by their mean scores of the post-test. This is in agreement with Klein (2008) and O'Hanlon (2007), who stated that language, writing (indirect vocabularies), and fluency are increased with the use of Facebook. These results are also in accord with Ajisoko (2020) study. However, thought the Ajisoko (2020) investigated students' vocabulary learning as a dependent variable, it is different from the current study in terms of its independent variable; i.e., the use of Duolingo Apps. Unlike the current study, Ajisoko (2020) used descriptive statistics and compared the students' scores in the pretest with the posttest only. Accordingly, the current study is different from this study in terms of research design, independent variables, and data analysis.

These types of improvement can be due to many factors. The first factor is the usefulness, ease of use, and accessibility of Facebook as a platform of learning. All students enrolled in the study were so familiar with using Facebook as they already have created their Facebook accounts and used them frequently for social activities. This fact is in harmony with Albashtawi and Al Bataineh (2020) study. However, the difference between this study and the current study is that in the former, student' reading and writing performance and their attitudes were targeted as they are influenced by the use of Google Classroom integrated English language learning environment. Second, the students had the opportunity to review and benefit from the myriad of activities and strategies while acquiring vocabulary items, rather than limiting themselves to merely paper related activities. Third, the ambiance of this interactive platform; i.e., Facebook has created a community of practice among students, specifically those who are shy, introverted, and weak in terms of their language knowledge. This can promote students' level of motivation and confidence and encourage them to interact, exchange ideas with the community of learners without any type of embarrassment. This fact is supported by Challob (2018) when he stated that the online learning platforms enhanced students' English language learning as the students are more flexible, less threatened and anxious when learning online due to the time and place flexibility of the learning situation. In addition to learning English vocabularies, the use of Facebook as a learning platform can also enhance students' autonomy and motivation.

In addition, the results of the study indicated that there are several factors that positively affected their learning of English vocabulary. These factors are; the variety of teaching techniques and activities, effective group work, immediate feedback, and autonomous learning opportunities that satisfy students' needs. As perceived by the EFL students, these factors are facilitated by the use of a technology-supported learning platform. These factors came in tandem with some of the previous studies such as (Buckman, 2005; Blattner \& Fiori, 2009; Abdullah, et al., 2019; Appavoo, 2019; Bilgic \& Tuzun, 2020) that reflected students' acceptance of various forms of technology-supported English language learning environments. The aforementioned factors helped students promote their vocabulary knowledge due to the interactive group work activities facilitated by Facebook platform. This created a comfortable and user-friendly learning environment for the students where they socialize, interact and learn by themselves under the supervision of their teacher. This fact is emphasized by Vygotsky's (1978) theory of social constructivism. This theory of learning proposed that learning is a social process and learning can be achieved via students' self-construction of knowledge and socialization (Can, 2009). Accordingly, students' enriched their English vocabulary knowledge via their continuous interaction in Facebook platform and leads to self-learning opportunities for English vocabularies. In addition, students' familiarity with all Facebook properties and their interest in using it encourage them to be engaged and interactive in the various learning activities that enriched their vocabulary knowledge.

Moreover, the study also revealed a few factors that negatively affected EFL students' learning of English vocabularies such as; domination of the good students of the discussion and work, technical problems, and social loafing. As perceived by the EFL students, these factors hinder their learning of English vocabularies throughout FOLP they have experienced. This result is in accord with some studies such as (Appavoo, 2019; Bilgic \& Tuzun, 2020). 


\section{CONCLUSION}

Based on the results gained in this study, it is clearly evidenced that the use of FOLP is effective in enhancing students' vocabulary knowledge. Accordingly, Facebook could be implemented as a supplemental learning experience that provides EFL students with an array of new meaningful strategies to enhance their skills and stimulate them to learn. In addition, Facebook represents a safe and less threatening learning space for shy and low self-esteem students as it provides them with meaningful learning opportunities and a flexible atmosphere to learn together by participating in collaborative learning activities. This flexible learning space enhances students' motivation and confidence and can consequently enrich students' vocabulary knowledge. Moreover, Facebook permits for meaningful learning of words in context. Thus, the students can learn not only the lexical meaning of words but also learn how to use the words in their appropriate contexts. Furthermore, the use of Facebook as a platform of learning encourages incidental learning of English vocabularies which in turn considered more enjoyable and motivating for EFL students (Northcote \& Kendle, 2010).

While the results of the current study are promising, few drawbacks should be highlighted and objectively taken in concern when dealing with the results of the research. This study has its limitations in terms of the short time duration of the study and the number of students involved. To some extent, the short time frame given was not so sufficient to deeply analyze the improvement of the students' vocabulary knowledge as it is affected by the used instructional strategy. This is due to the small time allocated for students to learn in the Facebook online community and the busy schedules that require them to do so many educational commitments. However, the use of mixed-mode research methodology, helped the researchers to diminish the drawbacks resulted from the short period of the experiment and consequently, proved the effectiveness of using Facebook in enriching students' vocabulary knowledge. To add further, the results of the study are restricted to $72 \mathrm{EFL}$ students who were enrolled in their 4th-year secondary school. Therefore, bigger sample size is also needed to conduct a similar study to enhance the validity and generalizability of the findings.

Based on the findings of the current study, along-period experimental studies are recommended to be conducted to investigate the effects of using Facebook on enhancing students' vocabulary knowledge. Further studies are encouraged to investigate the factors that affect students' English vocabulary learning as perceived by teachers of English language and other practitioners in the field. Finally, further studies should concentrate on the way teachers can do to diminish the effect of the challenging factors that hider students' learning of English vocabularies in SNSs in general and in Facebook in particular.

\section{BIODATA and CONTACT ADDRESSES of AUTHORS}

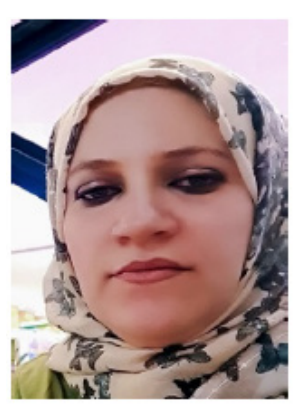

Majida Ibrahim MUKHLIF (M.A.) is currently assistant teacher in the field of English language teaching methods especially in information communication technology (ICT). She attained her master degree from Malaysia/University Sains Malaysia (USM) in department of Teaching English to Speakers of Other Languages (TESOL) at 24 July 2012. She has published many research articles in local journals. She works at Ministry of Education-General Directorate of Education in Al-Anbar.

\footnotetext{
Majida Ibrahim MUKHLIF

Directorate of Education in Al-Anbar.

Address: Anbar, IRAQ

Phone: +9647831990640

E-mail: shinestar1982@yahoo.com
} 


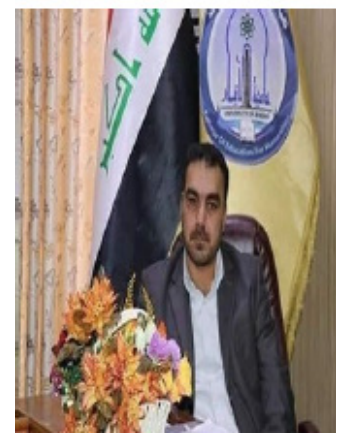

Dr. Ala'a Ismael CHALLOB (Ph.D.) is currently an associate professor in the field of Applied Linguistics/Computer Assisted Language Learning in the University of AnbarIraq. He attained his Ph.D. Degree from the National University of Malaysia (UKM) at July, 2018. Dr. Ala'a has been a university professor since 2003 where he has taught many courses in his field of study at both undergraduate and postgraduate studies. In addition, he has appointed as an internal and external examiner for many postgraduate students. He also acted as a member of the postgraduate committee for many years. Dr. Ala'a has published many research articles in international Scopus journals. His research interests are Applied Linguistics, Blended Learning, Flipped Learning, and Computer Assisted Language. He also cooperated with many international journals as an editorial member and reviewer in the field of his expertise.

\section{Ala'a Ismael CHALLOB}

College of Education for Humanities, University of Anbar.

Address: Dept. of English, College of Education for Humanities University of Anbar, Anbar, IRAQ 00964, Anbar, IRAQ

Phone: +9647825070330

E-mail: dr.alaaismael@uoanbar.edu.iq

\section{REFERENCES}

Abdullah, M. Y., Hussin, S., \& Ismail, K. (2019). Investigating the effects of the flipped classroom model on Omani EFL learners' motivation level in English speaking performance. Education and Information Technologies, 24(5), 2975-2995.

Abdullah, M. Y., Hussin, S., \& Ismail, K. (2019). Implementation of flipped classroom model and its effectiveness on English speaking performance. International Journal of Emerging Technologies in Learning (iJET), 14(09), 130-147.

Ajisoko, P. (2020). The use of Duolingo Apps to improve English vocabulary learning. International Journal of Emerging Technologies in Learning (iJET), 15(07), 149-155.

Albashtawi, A., \& Al Bataineh, K. (2020). The effectiveness of Google Classroom among EFL students in Jordan: An innovative teaching and learning online platform. International Journal of Emerging Technologies in Learning (iJET), 15(11), 78-88.

Appavoo, P., Sukon, K. S., Gokhool, A. C., \& Gooria, V. (2019). Why does collaborative learning not always work even when the appropriate tools are available?. Turkish Online Journal of Distance Education, 20(4), 11-30.

Aznar Díaz, I., Hinojo Lucena, F. J., Cáceres Reche, M. D. P., \& Romero Rodríguez, J. M. (2020). Pedagogical approaches in the knowledge society: The flipped classroom method for the development of creativity and dialogical learning. International Journal of Emerging Technologies in Learning (iJET), 15(03), 4-14.

Bilgic, H. G., \& Tuzun, H. (2020). Issues and challenges in web-based distance education programs in turkish higher education institutes. Turkish Online Journal of Distance Education, 21(1), 143-164.

Blachowitz, C., \& Fisher, P. (2006). Teaching vocabulary in all classroom. USA: Prentice-Hall Inc.

Blattner, G., \& Fiori, M. (2009). Facebook in the language classroom : Promises and possibilities. . Innovations in Education and Teaching International, 42(3), 247-256.

Buckman, R. (2005). Too much information? Colleges fear students' posting on facebook site could pose security risks. The Wall Street Journal. P. B1.

Can, T. (2009). Learning and teaching languages online: A constructivist approach. Novita-Royal, 3(1), 6074. 
Cetinkaya, L., \& Sutcu, S. S. (2018). The effects of Facebook and WhatsApp on success in English vocabulary instruction. Journal of Computer Assisted Learning, 34(5), 504-514.

Cetinkaya, L., \& Sutcu, S. S. (2019). Students' success in English vocabulary acquisition through multimedia annotations sent via WhatsApp. Turkish Online Journal of Distance Education, 20(4), 85-98.

Challob, A.I. (2018). Collaborative blended learning in EFL writing: A study on Students' writing apprehension, writing performance, and perception. (Unpublished doctoral dissertation). The National University of Malaysia.

Challob, A.I., Bakar, N. A., \& Latif, H. (2016). The influence of blended learning on EFL students' writing apprehension and writing performance: A qualitative case study. European Journal of Multidisciplinary Studies, 1(2), 253-265.

Cheung, R., \& Vogel, D. (2011). Can Facebook enhance the communications between teachers and students? The International Journal of Learning, 17(11), 385-397.

Creswell, J.W. (2012). Educational research: Planning, conducting, and evaluating quantitative and qualitative research. 4th Ed. Boston: Pearson Education, Inc.

Creswell, J. W. (2014). Research design: Qualitative, quantitative, and mixed methods approaches (4th ed.). Los Angeles: Sage publications, Inc.

Dehham, S. H. (2018). The role of contextualized testing technique in enhancing EFL intermediate students' capacity in acquiring English vocabulary. Sumerianz Journal of Education, Linguistics and Literature, 1(6), 128-136.

Denzin, N. K., \& Lincoln, Y. S. (Eds.). (2018). The sage handbook of qualitative research. (5th ed.). Los Angeles: Sage publications, Inc.

Gay, L. R., Mills, G. E., \& Airasian, P. (2009). Educational research: Competencies for analysis and applications (9th ed.). New Jersey: Pearson Education Inc.

Hair, J. F., Hollingsworth, C. L., Randolph, A. B., \& Chong, A. Y. L. (2017a). An updated and expanded assessment of PLS-SEM in information systems research. Industrial Management \& Data Systems, $117(3), 442-458$.

Jafari, S., \& Chalak, A. (2016). The role of WhatsApp in teaching vocabulary to Iranian EFL learners at junior high school. English Language Teaching, 9(8), 85-92.

Kabilan, M. K., \& Zahar, T. Z. M. E. (2016). Enhancing students' vocabulary knowledge using the Facebook environment. Indonesian Journal of Applied Linguistics, 5(2), 217-230.

Kern, R. G. (1996). Restructuring classroom interaction with networked computers: Effect on quantitiy and characteristics of language production. The Modern language journal, 79, 4(457-476).

Khe, F.H. (2011). Students' and teachers' use of Facebook. Computers in Human Behaviour, 27(2), 662-676.

Klein, J. (2008). Social networking for the K-12 set. Learning and leading with technology, 35(5), 12-16

Lee, J. S. (2019). Informal digital learning of English and second language vocabulary outcomes: Can quantity conquer quality?. British Journal of Educational Technology, 50(2), 767-778.

Liu, J.-h. (2009). The integration of CALL to vocabulary teaching and learning. US-China Foreign Language, 7(7), 60-64.

Majida, I. M. (2020). Students' perceptions on using Facebook for learning English at Al-Anbar University. Journal of Scientific and Educational Studies. 15(2), 403-423.

McCarthy, M. J. (1996). Vocabulary. Oxford: Oxford University Press.

Monica-Ariana, S., \& Anamaria-Mirabela, P. (2014). The impact of social media on vocabulary learning case study-Facebook. Annals of the University of Oradea, Economic Science Series, 23(2). 
Motlagh, H. S., Khafaie, H., Arastoo, A. A., Cheraghi, M., \& Khafaie, M. A. (2020). Application of social network in traditional sciences education on the vocabulary acquisition of secondary English learner students. Education and Information Technologies, 1-15.

Newby, P. (2014). Research methods for education. (2nd ed.). Routledge: Taylor \& Francis Group.

Nikbakht, E., \& Boshrabadi, A. M. (2015). Analysing the potential of social networking sites on EFL learners' vocabulary mastery: A situated-learning approach. Theory and Practice in Language Studies, 5(8), 1635-1641.

Northcote, M., \& Kendle, A. (2010). Informal networks for leraning: Making use of incidental leraning through recreation. Paper presented at the International Education Research Conference. December 2-6, Fremantle, Australia.

O'Hanlon, C. (2007). If you can't beat 'em, join 'em. The journal, 34(8), 39-44.

Pennington, M. (1989). Teaching languages with computers: The state of art. La Jolla, CA: Athelstan.

Rose, T. I. (2006). A guide to increase your vocabulary knowledge. Penang, Malaysia: EQUSAINS.

Roth, A. (2009). Following Plato's advice: Pedagogy and technology for the Facebook generation. Journal of Philosophy and History Education, 59, 125-128.

Schmitt, N., \& McCarthy, M. (1997). Editors' comments - acquisition section. In N. Schmitt, \& M. McCarthy (Eds.), Vocabulary: description, acquisition and pedagogy (228-236). Cambridge: Cambridge University Press.

Sharokani, S. (2009). Second language incidental vocabulary learning: The effect of online textual,pictorial and textual glosses. TESL-EJ, 13(3), 1-17.

Shetzer, H., \& Warschauer, M. (2000). An electronic literacy approach to network-based langauge teaching. In M. Warschauer \& R.Kern (Eds.), Network-based language teaching: Concepts and practice (pp. 171-185). Cambridge: Cambridge University Press.

Stake, R. E. (2010). Qualitative research: Studying how things work. New York: Guilford Press.

Talan, T., \& Gulsecen, S. (2019). The effect of a flipped classroom on students' achievements, academic engagement and satisfaction levels. Turkish Online Journal of Distance Education, 20(4), 31-60

Tosun, S. (2015). The effects of blended learning on EFL students' vocabulary enhancement. Procedia-Social and Behavioral Sciences, 199(1), 641-647.

Waring, R. (2008). How should teachers incorporate vocabulary teaching in their classes? Retrieved June 20, 2019 from http; //wwwl.harenet.ne.jp/waring/papers/eltnews.html

Warschauer, M. (1996). Comparing face to face and electronic communication in second langauge classroom. CALICO Journal, 13(2), 7-26.

Yin, R.K. (2011). Qualitative research from start to finish. New York: Guilford Press. 